\title{
PENGARUH CAR DAN FDR TERHADAP PEMBIAYAAN MURABAHAH DENGAN NPF SEBAGAI VARIABEL MODERATING
}

\author{
Evita Yulyani, Nana Diana \\ Universitas Singaperbangsa Karawang \\ Email: evitayln@yahoo.com, nanadiana.ekonomi@gmail.com
}

\begin{abstract}
This study aims to know the effect of CAR and FDR variables on Murabahah financing partially and simultaneously, besides, this study also examined the influence of NPF variables in moderating the relationship between independent variables and Murabahah financing. This research is a quantitative study with a sample of 11 (eleven) Syariah Commercial Banks registered with the Otoritas Jaa Keuangan in 2015-2019 that meet the researchers' criteria. The data used in this study is secondary data in the form of financial statements obtained from the website of each bank that is a sample of research. The results showed that CAR had no effect and significant on Murabahah financing, FDR had no effect and significant on Murabahah financing, and also simultaneously CAR and FDR did not affect muarabah financing. On the other side, the NPF as moderating variable show that a map to the CAR on Murabahah financing, the NPF moderating the FDR on Murabahah financing, and also the NPF moderating the influence of CAR and FDR on Murabahah financing simultaneously.
\end{abstract}

Keywords: CAR, FDR, NPF, Murabahah Financing

Abstrak: $\quad$ Penelitian ini bertujuan untuk mengetahui pengaruh variabel CAR dan FDR terhadap pembiayaan Murabahah secara parsial dan simultan, selain itu penelitian ini juga meneliti pengaruh variabel NPF dalam memoderasi hubungan antara variabel-variabel independen dengan pembiayaan Murabahah. Penelitian ini merupakan penelitian kuantitatif dengan sampel 11 (sebelas) Bank Umum Syariah yang terdaftar di Otoritas Jasa Keuangan di tahun 2015-2019 yang memenuhi kriteria peneliti. Data yang digunakan dalam penelitian ini merupakan data sekunder berupa laporan keuangan yang didapatkan dari website masing-masing Bank yang menjadi sampel penelitian. Hasil penelitian menunjukan bahwa CAR tidak berpengaruh terhdapat pemebiayaan Murabahah, FDR tidak berpengaruh terhadap pembiayaan Murabahah, dan juga secara simultan CAR dan FDR tidak berpengaruh terhadap pembiayaan muarabah. Sedangkan untuk hasil penelitian terkait variabel moderasi menyatakan bahwa NPF memoderasi pengaruh CAR terhadapat pembiayaan Murabahah namun NPF memoderasi pengaruh FDR terhadap pembiayaan Murabahah, dan juga NPF memoderasi pengaruh CAR dan FDR terhadap pembiayaan Murabahah secara simultan.

Kata Kunci: CAR, FDR, NPF, Pembiayaan Murabahah

\section{A. PENDAHULUAN}

Industri perbankan sering dianggap sebagai jantungnya dan motor penggerak perekonomian suatu negara ${ }^{1}$. Sama hal nya dengan negara Indonesia, industri perbankan memiliki peran yang sangat penting dalam perekonomian sebagaimana diatur dalam pasal 1 ayat (2) UU No. 10 Tahun 1998 tentang perubahan UU No. 7 Tahun 1992 yang menyatakan bahwa perbankan adalah badan usaha yang menghimpun dana dari masyarakat dalam bentuk kredit

${ }^{1}$ H Bachtiar Simatupang, "Peranan Perbankan Dalam Meningkatkan Perekonomian Indonesia," Jurnal Riset Akuntansi Multiparadigma 6, no. 2 (2019), hlm. 136-146. 
ataupun pinjaman dalam bentuk lain dalam rangka meningkatkan taraf hidup rakyat ${ }^{2}$. Bank di Indonesia dibedakan menjadi dua jenis, yaitu bank konvensional dan bank syari' $\mathrm{ah}^{3}$.

Di Indonesia sendiri bank syariah mulai dilirik semenjak krisis pada tahun 1997, hal ini ini disebabkan karena ada saat itu bank syariah menjadi bank yang menunjukan performa yang relative lebih baik dibanding dengan bank konvesnsional. Menurut data yang didapatkan dari Otoritas Jasa Keuangan (OJK) total Bank Umum Syariah di Indonesia saat ini mencapai 14 unit, dengan Unit Usaha Syariah (UUS) berjumlah 34 unit dan Bank Perkreditan Rakyat Syariah (BPRS) berjumlah 167 unit. $^{4}$

Seperti bank pada umumnya, bank syariah juga bertugas untuk menghimpun dan menyalurkan dana untuk masyarakat berdasarkan pada prinsip syariat islam. Bank menghimpun dana dalam wujud simpanan dan menyalurkannya dalam bentuk pembiayaan. Pembiayaan bank syariah berbeda dengan bank konvensional, bank syariah menggunakan sistem bagi hasil. Penyaluran dana pada bank syariah terbagi menjadi beberapa bagian yaitu prinsip bagi hasil (musyarakah dan mudharabah), prinsip sewa menyewa (ijarah dan ijarah muntahiyah bit tamlik), prinsip jual beli (Murabahah, salam, dan istishna'), prinsip jasa (hilawah, rahn, wakalah, kafalah, dan qardh).

Pada periode Januari-September 2018, Bank Muamalat mencatat laba bersih sebesar Rp 108,79 miliar, meningkat dua kali lipat dari tahun sebelumnya yakni Rp 45,07 miliar. Namun hingga kuarta II-2018, Bank Muamalat mencatat pertumbuhn negatif pada beberapa rasio keuangan. Pada sisi pembiayaan, penurunan signifikan tercatat pada piutang Murabahah sebesar Rp 3,72 triliun, aset tercatat pada akhir 2017 sebesar Rp 27,02 triliun, sementara pada akhir September 2018 tercatat Rp 23,29 triliun. Pada kuartal II-2018 Bank Muamalat mencatat NPF gross sebesar 2,98\% dan net 2,5\%, naik signifikan dibanding kuartal II-2018 yang tercatat 1,65\% secara gross dan $0,88 \%$ secara net. Peningkatan NPF tersebut berperan menggerus CAR menjadi $12,12 \%$ pada akhir September 2018, sementara tiga bulan sebelumnya masih tercatat $15,92 \%$.

Tabel 1. Data Penyaluran Pembiayaan Bank Umum Syariah (Dalam Miliyar Rupiah)

\begin{tabular}{c|r|r|r|r|r}
\hline & $\mathbf{2 0 1 5}$ & \multicolumn{1}{c|}{$\mathbf{2 0 1 6}$} & \multicolumn{1}{c|}{$\mathbf{2 0 1 7}$} & $\mathbf{2 0 1 8}$ & \multicolumn{1}{c}{$\mathbf{2 0 1 9}$} \\
\hline Mudharabah & 7.979 & 7.577 & 6.584 & 5.477 & 5.413 \\
\hline Musyarakah & 47.357 & 54.052 & 60.465 & 68.644 & 84.582 \\
\hline Murabahah & 93.642 & 110.063 & 114.456 & 118.134 & 122.751 \\
\hline Qardh & 3.308 & 3.883 & 5.476 & 6.848 & 9.276 \\
\hline Istishna & 120 & 25 & 18 & 15 & 11 \\
\hline Ijarah & 1.561 & 1.882 & 2.788 & 3.180 & 3.138 \\
\hline
\end{tabular}

Sumber: Statistik Perbankan Syariah, $2019^{5}$

\footnotetext{
${ }^{2}$ Bank Indonesia, "Peraturan Bank Indonesia Nomor 15/12/PBI/2013 Tentang Kewajiban Penyediaan Modal Minimum Bank Umum,” Bank Indonesia (2013), hlm. 1-80.

${ }^{3}$ Yenni Annor Vivin and Budi Wahono, "Analisis Perbandingan Kinerja Keuangan Bank Umum Syariah Dengan Bank Umum Konvensional Di Indonesia,” e-Jurnal Riset Manajemen (2017), hlm. 15-28.

${ }^{4}$ Bank Indonesia, Statistik Perbankan Syariah Desember 2019, 2019, https://www.ojk.go.id/id/kanal/syariah/data-dan-statistik/statistik-perbankan-syariah/Documents/Pages/StatistikPerbankan-Syariah---Desember-2019/SPS Desember 2019.pdf.

${ }^{5}$ Ibid.
} 
Dari grafik diatas dapat dilihat bahwa pembiayaan dengan akad Murabahah menjadi penyaluran pembiayaan dengan porsi paling besar menurut data Otoritas Jasa Keuangan (OJK). Bai'al-Murabahah yaitu aktivias jual beli pada harga pokok dengan tambahan profit yang disepakati ${ }^{6}$. Dalam hal ini penjual patut memberitahukan harga pokok yang dibeli ditambah dengan profit yang diharapkannya. Salah satu alasan mengapa Murabahah menjadi instrument yang banyak diterapkan dalam aktivitas pembiayaan adalah karena Murabahah pada dasarnya merupakan kontrak jual beli yang profitnya telah ditentukan diawal transaksi ${ }^{7}$. Tingginya porsi pembiayaan Murabahah pada bank syariah juga disebabkan karena pembiayaan ini dinilai lebih mudah dan tidak membutuhkan analisis yang rumit juga menguntungkan bagi kedua pihak yaitu pihak bank dan pihak nasabah. Salah satu faktor yang mem pengaruhi tinggi rendahnya pembiayaan Murabahah pada bank syariah adalah Capital Adeuacy Ratio (CAR), Financing to Deposit Ratio (FDR), dan Non Performing Financing (NPF).

\section{Gambar 1. Data Rasio Keuangan Bank Umum Syariah}

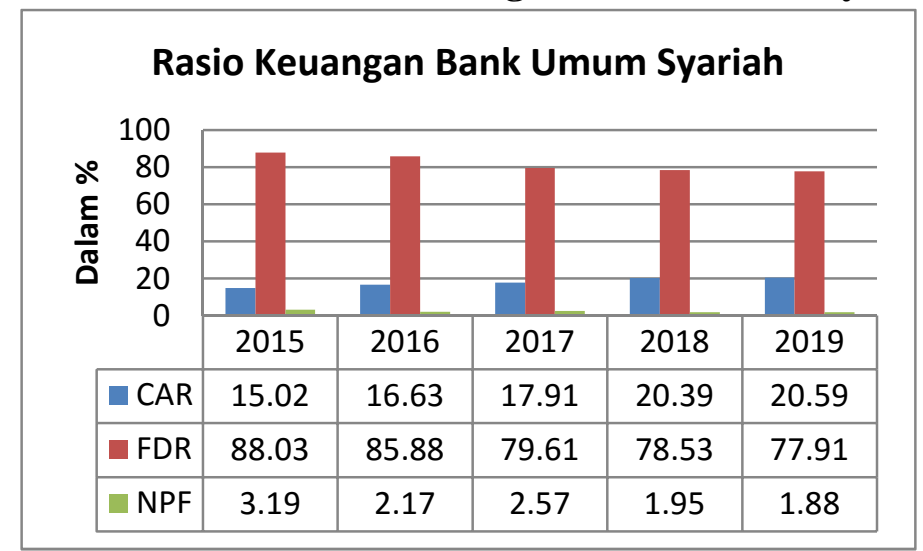

Sumber: Statistik Perbankan Syariah, $2019^{8}$

Pembiayaan yang akan diberikan kepada nasabah harus disesuaikan dengan kecukupan dana yang dimiliki bank syariah itu sendiri. Tanpa dana yang cukup, bank tak bisa berbuat apa-apa, atau dengan kata lain bank menjadi tak berfungsi sama sekali. Kecukupan dana yang dimiliki bank syariah dapat dilihat dari rasio Capital Adequacy Ratio (CAR), dilihat dari gambar 2 CAR pada bank umum syariah selalu mengalami kenaikan setiap tahunnya, dengan kata lain bank selalu memiliki cukup data untuk memenuhi pembiayaan yang diinginkan nasabah yang selalu meningkat. Beberapa penelitian terdahulu membahas tentang pengaruh CAR terhadap pembiayaan Murabahah, diantaranya penelitian yang dilakukan oleh Nafidzatun, Hulaikhah dan Arif $(2020)^{9}$, Vien dan Sofyan $(2017)^{10}$ dan Haqqi (2016) ${ }^{11}$ yang menunjukan CAR berpengaruh negatif terhadap pembiayaan Murabahah. Hal berbeda ditunjukan dari hasil

${ }^{6}$ Khaerul Umam, "Manajemen Perbankan Syariah” (2019).

${ }^{7}$ Dewa P K Mahardika, “Mengenal Lembaga Keuangan,” Bekasi: Gramata Publishing (2015).

${ }^{8}$ Indonesia, Statistik Perbankan Syariah Desember 2019.

${ }^{9}$ Nunuk Nafidzatun, Mifta Hulaikhah, and Ahmad Arif, "Pengaruh CAR, NPF Dan FDR Terhadap Pembiayaan Murabahah Pada Bank Umum Syariah Di Indonesia,” Jurnal Ekonomi Syariah 5, no. 2 (2020), hlm.140-152.

${ }^{10}$ Ratu Vien Sylvia Aziza and A D E Sofyan Mulazid, “Analisis Pengaruh Dana Pihak Ketiga, Non Performing Financing, Capital Adequacy Ratio, Modal Sendiri Dan Marjin Keuntungan Terhadap Pembiayaan Murabahah," Jurnal Ekonomi dan Bisnis Islam (JEBI) 2, no. 1 (2017), hlm. 1-15.

${ }^{11}$ Hibatul Haqqi, "Analisis Pengaruh Non Performing Financing (NPF), Financing To Deposit Ratio (FDR), Inflasi Dan Capital Adequacy Ratio (CAR) Terhadap Proporsi Pembiayaan Murabahah Pada Bank Umum Syariah Di Indonesia," skripsi (2016). 
penelitian Kusnianingrum dan Riduwan $(2016)^{12}$ dan Riyadi dan Muhcamad (2018) ${ }^{13}$ yang menyatakan bahwa CAR berpengaruh positif terhadapat permbiayaan Murabahah.

Dalam rangka menciptakan performa bank yang baik dalam hal pembiayaan dapat diperhatikan dari membaiknya rasio pembiayaan Dana Pihak Ketiga (DPK) yang biasa disebut Financing to Deposit Ratio (FDR). FDR menunjukan efektif tidaknya bank dalam menyalurkan pembiayaan, semakin banyak dana yang bisa disalurkan dalam pembiayaan maka semakin tinggi earning asset ${ }^{14}$. Dari penelitian sebelumnya ditemukan hasil bahwa FDR berpengaruh positif terhadapat pembiayaan Murabahah menurut Kusnianingrum dan Riduwan (2016) ${ }^{15}$ sedangkan menurut penelitian yang dilakukan oleh Haqqi (2016) ${ }^{16}$ ditemukan hasil bahwa FDR berpengaruh negatif terhadap pembiayaan Murabahah.

Setelah bank syariah berhasil menghimpun dana untuk dijadikan modal, selanjutnya bank syariah akan menyalurkan dana tersebut melalui pembiayaan, hal ini dilakukan agar bank mendapatkan keuntungan. Namun realitanya bank syariah tidak selalu mendapatkan keuntungan dari pembiayaan yang diberikan kepada nasabah, bank juga harus menghadapi kenyataan jika ternyata dipertengah jalan bank syariah mendapatkan pembiayaan bermasalah (Non Performing Financing). NPF ini memberikan dampak buruk bagi bank diantaranya adalah hilangnya peluang bank untuk mendapatkan profit dari penyaluran pembiayaan yang diberikan kepada nasabah. Melihat dari grafik diatas, meningkatnya pembiayaan Murabahah dibarengi dengan menurunnya NPF pada BUS selama lima tahun terakhir.

Berdasarkan uraian diatas, adanya research gap dan ketidak pastian hasil dari penelitian terdahulu, maka diperlukan penelitian ulang mengenai analisis rasio yang mempengaruhi pembiayaan Murabahah pada bank syariah. Penelitian kembali perlu dilakukan dengan menambahkan Non Performing Financing (NPF) sebagai variabel moderating dengan harapan hasil penelitian nantinya dapat mempertegas dan memperkuat teori yang ada. Non Performing Financing (NPF) sebagai variabel moderating pengaruh Capital Adeqaucy Ratio (CAR) dan Financing to Deposit Ratio (FDR) terhadap pembiayaan Murabahah, hal ini dikarenakan NPF yang tinggi akan berimbas pada penurunan modal dan kesulitan likuiditas pada bank sehingga akan mengurangi jumlah pembiayaan yang disalurkan ${ }^{17}$. Dengan demikian dapat disimpulkan tujuan dari penelitian ini adalah untuk mengetahui apakah CAR dan FDR terhadap Pembiayaan Murabahah dengan NPF sebagai variabel moderating.

\footnotetext{
${ }^{12}$ Devi Kusnianingrum and Akhmad Riduwan, "Determinan Pembiayaan Murabahah (Studi Pada Bank Syariah Mandiri),” Jurnal Ilmu dan Riset Akuntansi 5, no. 1 (2016), hlm. 1-19.

${ }^{13}$ Selamet Riyadi and Rais Muhcamad Raffii, "Pengaruh Dana Pihak Ketiga, Capital Adequacy Ratio, Bi Rate, Dan Financing To Deposit Ratio Terhadap Pembiayaan Murabahah Pada Bank Syariah Di Indonesia," Perbanas Rerview 3, no. 2 (2018), hlm. 18.

${ }^{14}$ Farida Idayati Joana Ryca Rachmawaty, "Analisis Faktor-Faktor Yang Mempengaruhi Pembiayaan Jual-Beli Murabahah Pada Perbankan Syariah Di Indonesia,” jurnal ilmu dan riset manajemen 6, no. 9 (2017), hlm.1-24.

Mandiri)."

${ }^{15}$ Kusnianingrum and Riduwan, "Determinan Pembiayaan Murabahah (Studi Pada Bank Syariah

${ }^{16}$ Haqqi, “Analisis Pengaruh Non Performing Financing (Npf), Financing To Deposit Ratio (Fdr), Inflasi Dan Capital Adequacy Ratio (Car) Terhadap Proporsi Pembiayaan Murabahah Pada Bank Umum Syariah Di Indonesia."

${ }^{17}$ (Oktaviani, 2012)
} 


\section{B. METODE PENELITIAN}

Jenis penelitian yang digunakan dalam peneltian ini ialah penelitian kuantitatif. Penelitian kuantitatif yaitu ragam penelitian yang menciptakan temuan yang bisa dicapai dengan menerapkan prosuder-prosedur statistik atau metode lain dari kuantifikasi ${ }^{18}$. Sumber data yang digunakan dalam penelitian ini adalah data sekunder berupa data laporan keuangan tahunan dan rasio keuangan Bank Umum Syariah periode 2015-2019 yang diambil langsung dari website www.ojk.co.id dan dari website resmi masing-masing Bank Umum Syariah yang menjadi sampel dalam penelitian ini.

Sampel adalah bagian dari jumlah dan karakteristik yang dimiliki oleh populasi tersebut $^{19}$. Sample dalam penelitian ini adalah bagian dari jumlah populasi Bank Umum Syariah yang terdaftar di Otoritas Jasa Keuangan (OJK) sebanyak 11 Bank. Dalam penelitian ini peneliti menggunakan teknik Purposive Sampling untuk pengambilan sampel. Purposive Sampling yakni teknik penentuan sampel dengan pertimbangan atau kriteria tertentu. Adapun kriteria yang digunakan untuk menentukan sampel dalam penelitian ini adalah sebagai berikut:

Tabel 2. Kriteria Penyeleksian Bank Umum Syariah

\begin{tabular}{c|l|c}
\hline No & \multicolumn{1}{c}{ Keterangan } & Jumlah \\
\hline $\mathbf{1}$ & $\begin{array}{l}\text { Bank Umum Syariah yang terdaftar di Bursa Efek } \\
\text { Indonesia (BEI) pada tahun 2015-2019. }\end{array}$ & 14 \\
\hline $\mathbf{2}$ & $\begin{array}{l}\text { Bank Umum Syariah yang terdaftar di Indonesia dan } \\
\text { menerbitkan laporan keuangannya selama lima } \\
\text { tahun, yakni 2015-2019. }\end{array}$ & \\
\hline $\mathbf{3}$ & $\begin{array}{l}\text { Bank Umum Syariah yang menyertakan informasi } \\
\text { rasio-rasio keuangan yang dibutuhkan peneliti dalam }\end{array}$ & $(1)$ \\
\hline & $\begin{array}{l}\text { laporan keuangan yang dipublikasikan. } \\
\text { Total Sampel Penelitian }\end{array}$ & 11 \\
\hline Total Pengamatan $(\mathbf{1 1} \times \mathbf{5})$ & 55 \\
\hline
\end{tabular}

Sumber : Data diolah, 2021

Teknik analisis data yang digunakan penelitian ini adalah analisis regresi linier berganda, data diuji lewat uji asumsi klasik dan uji hipotesis. Uji asumsi klasik dilakukan untuk memastikan akurasi model yang digunakan pada penelitian. Uji hipotesis dilakukan untuk memastikan kebenaran hipotesis secara statistika dan menarik simpulan perihal diterima atau tidaknya hipotesis yang akan diajukan.

Definisi Operasional variabel ialah segala sesuatu yang ditentukan peneliti untuk dipelajari sehingga didapatkan informasi perihal data penelitian tersebut. Penelitian ini ialah penelitian kuantitatif yang berupaya mencari hubungan antara variabel independen dengan variabel dependen. Dalam penelitian ini terdapat tambahan variabel mediasi yang digunakan untuk mengetahui hubungan secara langsung ataupun tidak langsung terhadap variabel independen dan variabel dependen. Adapun variabel-variabel yang diterapkan dalam penelitian ini yaitu: Baru Pers (2016).

${ }^{18}$ V Wiratna Sujarweni, “Kupas Tuntas Penelitian Akuntansi Dengan SPSS," Yogyakarta: Pustaka

${ }^{19} \mathrm{P}$ D Sugiyono, "Metode Penelitian Bisnis: Pendekatan Kuantitatif, Kualitatif, Kombinasi, Dan R\&D,” Penerbit CV. Alfabeta: Bandung (2017). 


\section{Variabel Dependen (Y)}

Penelitian memakai variabel dependen yakni pembiayaan Murabahah. Murabahah disebut juga instrumen cost plus margin, yaitu instrumen pembiayaan ${ }^{20}$. Pembiayaan Murabahah yaitu transaksi jual beli antara penjual (bank syariah) dengan pembeli (nasabah) dalam hal ini penjual meberitahukan harga asli dan tambahan keuntungan (margin) yang sudah disepakati kedua pihak Persentase pembiayaan Murabahah dihitung dengan membandingkan antara jumlah pembiayaan Murabahah yang disalurkan dengan pembiayaan yang dberikan oleh pihak bank.

2. Variabel Independen $(\mathrm{X})$

Dalam penelitian ini terdapat variabel independen yakni:

a. Capital Adequecy Ratio (CAR) (X1)

CAR ialah rasio yang menunjukan seberapa jauh segala aktivitas bank yang mengandung risiko ikut serta dibiayai dari dana modal bank sendiri Dendawijawa (2015) dalam Marisya $(2019)^{21}$.

b. Financing to Deposit Ratio (FDR) (X2)

Financing to Deposit Ratio (FDR) adalah perbandingan antara kredit yang diberikan dengan dana pihak ketiga termasuk pinjaman subordinasi ${ }^{22}$.

3. Variabel Moderating (M)

Penelitian ini menggunakan variabel moderating yaitu Non Performing Financing (NPF). NPF adalah rasio yang menandakan kesanggupan bank dalam mengelola kredit bermasalah yang sudah disalurkan oleh bank kepada pihak ketiga (Muhammad 2005) dalam Efendy dan Fathoni (2019) ${ }^{23}$.

\section{HASIL DAN PEMBAHASAN}

\section{Uji Normalitas}

Uji Normalitas ini bertujuan untuk menguji apakah dalam model regresi variabel dependen dan variabel independen mempunyai distribusi normal ${ }^{24}$. Dalam penelitian ini, peneliti menggunakan uji non-parametrik Kolmogorov-Smirnov (K-S).

Tabel 3. Hasil Uji Normalitas

\begin{tabular}{|c|c|c|}
\hline & & Unstandardized Residual \\
\hline \multicolumn{2}{|l|}{$\mathrm{N}$} & 55 \\
\hline \multirow[t]{2}{*}{ Normal Parameters ${ }^{\mathrm{a}, \mathrm{b}}$} & $\begin{array}{l}\text { Mean } \\
\text { Std }\end{array}$ & $\begin{array}{r}, 0000000 \\
09010875507\end{array}$ \\
\hline & $\begin{array}{l}\text { Std. Deviation } \\
\text { Absolute }\end{array}$ & $\begin{array}{r}9901,088 / 5507 \\
141\end{array}$ \\
\hline \multirow[t]{2}{*}{ Most Extreme Differences } & Positive &, 126 \\
\hline & Negative &,- 141 \\
\hline Kolmogorov-S & & 1,045 \\
\hline Asymp. Sig. ( & & ,225 \\
\hline
\end{tabular}

Sumber: Data diolah, 2020

\footnotetext{
${ }^{20}$ Mahardika, "Mengenal Lembaga Keuangan."

${ }^{21}$ Fitria Marisya, "Analisis Pengaruh Struktur Modal (CAR) Dandana Pihak Ketiga (FDR) Terhadap Profitabilitas (ROA) Dengan Kredit Bermasalah (NPF) Sebagai Varibel Intervening Pada Perbankan Umum Syariah Di Indonesia," JAZ:Jurnal Akuntansi Unihaz 2, no. 2 (2019), hlm. 1.

${ }^{22}$ O.P Simorangkir, Pengantar Lembaga Keuangan Bank Dan Non Bank (Bogor: Ghalia Indonesia, 2000).

${ }^{23}$ Felix Efendy and Salman Fathoni, "Pengaruh Rasio Kinerja Bank Terhadap Profitabilitas Industri Bank Umum Syariah Di Indonesia,” Jurnal Ilmiah Ekonomi Islam 5, no. 3 (2019), hlm. 217.

${ }^{24}$ Sujarweni, "Kupas Tuntas Penelitian Akuntansi Dengan SPSS."
} 
Dari hasil pada tabel 3 dapat dilihat bahwa nilai K-S adalah 1,045 dengan signifikasi 0,225 lebih besar dari 0,05 dengan itu dapat disimpulkan bahwa data pada penelitian ini terdistribusi normal.

\section{Uji Multikolinieritas}

Uji multikolinieritas digunakan untuk mengetahui ada atau tidaknya kesamaan antar variabel independen dalam model. Kemiripan antar variabel indipenden akan mengakibatkan korelasi yang sangat kuat ${ }^{25}$.

\section{Tabel 4. Hasil Uji Multikolinieris}

\begin{tabular}{|c|c|c|c|c|c|c|c|c|}
\hline & \multicolumn{8}{|c|}{ Coefficients $^{\mathrm{a}}$} \\
\hline & \multirow[t]{2}{*}{ Model } & \multicolumn{2}{|c|}{ Unstandardized Coefficients } & \multirow{2}{*}{$\begin{array}{c}\begin{array}{c}\text { Standardized } \\
\text { Coefficients }\end{array} \\
\text { Beta }\end{array}$} & \multirow[t]{2}{*}{$\mathrm{T}$} & \multirow[t]{2}{*}{ Sig. } & \multicolumn{2}{|c|}{ Collinearity Statistics } \\
\hline & & $\mathrm{B}$ & Std. Error & & & & Tolerance & VIF \\
\hline \multirow{4}{*}{1} & (Constant) & 19573,651 & 3911,794 & & 5,004 &, 000 & & \\
\hline & CAR & $-325,022$ & 116,177 & $-1,101$ & $-2,798$ & ,007 &, 106 & 9,435 \\
\hline & FDR &, 101 &, 047 &, 824 & 2,142 & ,037 &, 111 & 9,019 \\
\hline & NPF & $-1074,786$ & 840,295 &,- 176 & $-1,279$ & ,207 &, 872 & 1,146 \\
\hline
\end{tabular}

a. Dependent Variable: Murabahah

Sumber: Data diolah, 2020

Berdasarkan hasil uji pada tabel diatas, diketahui bahwa perhitungan nilai tolerance menunjukan bahwa tidak ada variabel yang memiliki nilai kurang dari 0,10 dan hasil dari perthitungan nilai VIF setiap variabel juga menunjukan hal yang sama karena masih diantara nilai 1-10 yang berarti tidak terjadi multikolinieritas antar variabel independen dalam model regresi.

\section{Uji Autokorelasi}

Uji autokorelasi bertujuan untuk mengetahui ada tidaknya korelasi antara variabel pengganggu pada periode tertentu dengan variabel sebelumnya. ${ }^{26}$

Tabel 5. Hasil Uji Autokorelasi (Cochrane-Orcutt) Model Summary ${ }^{\mathrm{b}}$

\begin{tabular}{|r|r|r|r|r|r|}
\hline Model & $\mathrm{R}$ & R Square & $\begin{array}{c}\text { Adjusted R } \\
\text { Square }\end{array}$ & $\begin{array}{c}\text { Std. Error of the } \\
\text { Estimate }\end{array}$ & $\begin{array}{c}\text { Durbin- } \\
\text { Watson }\end{array}$ \\
\hline 1 &, $295^{\mathrm{a}}$ &, 087 &, 032 & 6036,62588 & 1,833 \\
\hline
\end{tabular}

b. Dependent Variable: Lag_Y

Sumber: Data diolah, 2020

Berdasarkan hasil uji autokorelasi pada tabel diatas, nilai Durbin-Watson (DW) adalah 1,833 dan akan dibandingkan dengan $\mathrm{DW}_{\text {tabel }}(\mathrm{k}, \mathrm{n})$ jadi $(3,55)$ diperoleh dU sebesar 1,6815 dan dL sebesar 1,4523. Setelah membandingkan nilai DW dengan $\mathrm{DW}_{\text {tabel }}$ maka nilai $\mathrm{DW}$ lebih besar dari nilai dU yaitu 1,6815 dan lebih kecil dari nilai 4-dL yaitu 2,5477. Hingga dapat diambil kesimpulan bahwa terjadi autokorelasi negative dalam model regresi ini.

\section{Uji Heteroskedastisitas}

Uji heteroskedastisitas bertujuan untuk menguji terjadinya perbedaan variance residual suatu periode pengamatan ke periode pengamatan yang lain. Model regresi yang baik yakni model yang tidak terjadi heteroskedastisitas ${ }^{27}$.

$$
\begin{aligned}
& { }^{25} \text { Ibid. } \\
& { }^{26} \text { Ibid. } \\
& { }^{27} \text { Ibid. }
\end{aligned}
$$




\section{Tabel 6. Hasil Uji White}

Model Summary ${ }^{\mathrm{b}}$

\begin{tabular}{|c|r|r|r|r|}
\hline Model & R & R Square & Adjusted R Square & Std. Error of the Estimate \\
\hline 1 &, $228^{\mathrm{a}}$ &, 052 &,- 004 & 175628507,13604 \\
\hline
\end{tabular}

a. Predictors: (Constant), NPF, FDR, CAR

b. Dependent Variable: RES3

Sumber: Data diolah, 2020

Dapat dilihat bahwa hasil uji white pada tabel diatas didapatkan nilai Chi-Square hitung $_{\text {Ca }}$ adalah $\mathrm{n} \times \mathrm{R}^{2}=55 \times 0,052=2,86$ lebih kecil dari nilai Chi-Square tabel $_{\text {(K-1 }}(\mathrm{K}-1=3-1=2)$ yaitu 5,9915 , maka dapat disimpulkan bahwa tidak terjadi heteroskedastisitas pada model regresi ini.

\section{Uji Linieritas}

Uji linieritas diaplikasikan untuk mengamati apakah spesifikasi model yang diterapkan telah benar atau tidak ${ }^{28}$.

Tabel 7. Hasil Uji Linieritas

ANOVA Table

\begin{tabular}{|c|c|c|c|c|c|c|c|}
\hline & & & Sum of Squares & $\mathrm{df}$ & Mean Square & $\mathrm{F}$ & Sig. \\
\hline \multirow{5}{*}{$\begin{array}{c}\text { Murabahah } * \\
\text { CAR }\end{array}$} & \multirow{3}{*}{$\begin{array}{c}\text { Between } \\
\text { Groups }\end{array}$} & (Combined) & 6118502509,745 & 52 & 117663509,803 & 1,177 & ,566 \\
\hline & & Linearity & 459548421,891 & 1 & 459548421,891 & 4,598 & , 165 \\
\hline & & $\begin{array}{c}\text { Deviation } \\
\text { from } \\
\text { Linearity }\end{array}$ & 5658954087,855 & 51 & 110959884,076 & 1,110 & ,587 \\
\hline & \multicolumn{2}{|c|}{ Within Groups } & 199880050,000 & 2 & 99940025,000 & & \\
\hline & \multicolumn{2}{|c|}{ Total } & 6318382559,745 & 54 & & & \\
\hline
\end{tabular}

Sumber: Data diolah, 2020

Dapat dilihat bahwa nilai Sig. deviatiaon from linierity sebesar 0,587 > 0,05 dengan itu dapat diambil kesimpulan bahwa terdapat hubungan yang linier antar variabel.

\section{Uji Hipotesis}

a. Uji Koefisien Determinasi $\left(\mathrm{R}^{2}\right)$

Koefisien determinan $\left(\mathrm{R}^{2}\right)$ pada dasarnya mengukur seberap jauh model dapat menjelaskan perubahan variabel dependen ${ }^{29}$

\section{Tabel 8. Hasi Uji $\mathbf{R}^{2}$}

Model Summary

\begin{tabular}{|c|r|r|r|r|}
\hline Model & R & R Square & \multicolumn{1}{|c|}{$\begin{array}{c}\text { Adjusted R } \\
\text { Square }\end{array}$} & $\begin{array}{c}\text { Std. Error of the } \\
\text { Estimate }\end{array}$ \\
\hline 1 &, $223^{\mathrm{a}}$ &, 050 &, 012 & 6098,47728 \\
\hline
\end{tabular}

a. Predictors: (Constant), FDR, CAR

Sumber: Data diolah, 2020

Angka Adjusted $R$ Square sebesar 0,012 menunjukan bahwa hanya 1,2\% variabel Pembiayaan Murabahah (Y) yang dipengaruhi oleh variabel CAR (X1) dan FDR (X2), sedangkan sisanya sebesar 98,8\% dipengaruhi variabel lain diluar penelitian ini.

\footnotetext{
${ }^{28}$ Imam Ghozali, "Aplikasi Analisis Multivariate Dengan Program IBM SPSS 21 Update PLS Regresi,” Semarang. Badan Penerbit Universitas Diponegoro. ISBN (2013).

${ }^{29}$ Ibid.
} 


\section{b. Uji Simultan (Uji F)}

Uji $\mathrm{F}$ bertujuan untuk menguji apakah seluruh variabel independen yang dimasukan ked dalam model memliki pengaruh secara bersama-sama kepada variabel dependen (Ghozali, 2013:98). Hasil uji $\mathrm{F}$ ini digunakan untuk menjawab hipotesis penelitian $\mathrm{H}_{3}$ yang menyatakan bahwa CAR dan FDR berpengaruh terhadap pembiayaan Murabahah secara simultan.

Tabel 9. Hasil Uji F

\begin{tabular}{|c|c|c|c|c|c|c|}
\hline \multicolumn{7}{|c|}{ ANOVA $^{a}$} \\
\hline & Model & Sum of Squares & Df & Mean Square & $\mathrm{F}$ & Sig. \\
\hline \multirow{3}{*}{1} & Regression & 99237879,207 & 2 & 49618939,604 & 1,334 &, $272^{\mathrm{b}}$ \\
\hline & Residual & 1896762680,669 & 51 & 37191425,111 & & \\
\hline & Total & 1996000559,876 & 53 & & & \\
\hline
\end{tabular}

Sumber: Data diolah, 2020

Dari data diatas dapat dilihat nilai $\mathrm{F}_{\text {hitung }}$ sebesar 1,334. Adapun nilai $\mathrm{F}_{\text {tabel }}$ pada tingkat signifikan 5\% dan derajat dfl $=(\mathrm{k}-1)=2-1=1$ dan df $2=(\mathrm{n}-\mathrm{k}-1)=55-2-1=52$, maka $F_{\text {tabel }}$ didapat $(1: 52)=4,027$ dengan kata lain $F_{\text {hitung }}<F_{\text {tabel. Nilai signifikansi } 0,272}$ lebih besar dari 0,05 , sihingga dapat diambil kesimpulan bahwa penelitan ini menolak $\mathrm{H}_{3}$ yang menyatakan jika CAR (X1) dan FDR (X2) berpengaruh terhadap Pembiayaan Murabahah (Y) secara simultan.

c. Uji Parsial (Uji t)

Uji t bertujuan untuk menguji seberapa jauh pengaruh satu variabel independen secara individual dalam menjelaskan ragam variabel dependen ${ }^{30}$. Hail uji t digunakan untuk menjawab hipotesis penelitian $\mathrm{H}_{1}$ dan $\mathrm{H}_{2}$.

Tabel 10. Hasil Uji t

Coefficients $^{\mathrm{a}}$

\begin{tabular}{|c|c|c|c|c|c|c|}
\hline & \multirow[t]{2}{*}{ Model } & \multicolumn{2}{|c|}{ Unstandardized Coefficients } & \multirow{2}{*}{$\begin{array}{c}\text { Standardized } \\
\text { Coefficients }\end{array}$} & \multirow[t]{2}{*}{$\mathrm{T}$} & \multirow[t]{2}{*}{ Sig. } \\
\hline & & B & Std. Error & & & \\
\hline \multirow{3}{*}{1} & (Constant) & 2750,159 & 895,075 & & 3,073 & 003 \\
\hline & CAR & $-99,424$ & 61,290 &,- 528 & $-1,622$ &, 111 \\
\hline & FDR & ,034 & ,024 & ,453 & 1,392 &, 170 \\
\hline
\end{tabular}

a. Dependent Variable: Murabahah

Sumber: Data diolah, 2020

Sebelum mengambil kesimpulan untuk menentukan apakah hipotesis penelitian $\left(\mathrm{H}_{1}\right.$ dan $\mathrm{H}_{2}$ ) yang diajukan diterima atau ditolak, terlebih dahulu perlu ditetapkan nilai $t_{\text {tabel }}$ yang akan digunakan dengan menggunakan uji dua sisi, dan untuk penelitian ini nilai $t_{\text {tabel }}$ yang ditetapkan adalah (sig. $\alpha=0,025 \mathrm{dan} \mathrm{df}=53$ ) 2,006. hasil analisis atas hipotesis penelitian $\left(\mathrm{H}_{1}\right.$ dan $\left.\mathrm{H}_{2}\right)$ dapat dilihat sebagai berikut:

1) $\mathrm{H}_{1}$ : Capital Adequacy Ratio $\left(\mathrm{X}_{1}\right)$ berpengaruh dan signifikan terhadap pembiayaan Murabahah.

Dari tabel 9 dapat dilihat bahwa variabel CAR memiliki $t_{\text {hitung }}$ sebesar $-1,622, t_{\text {hitung }}$ berada pada area Ha diterima dan Ho ditolak dengan tingkat signifikansi 0,111>0,05

${ }^{30}$ Ibid. 
maka $\mathrm{H}_{1}$ ditolak yang berarti CAR tidak berpengaruh terhadap pembiayaan Murabahah. Dapat diambil kesimpulan dari hasil uji pada tabel 9 ketika nilai CAR naik maka besarnya nilai pembiayaan akan menurun.

2) $\mathrm{H}_{2}$ : Financing to Deposit Ratio $\left(\mathrm{X}_{2}\right)$ berpengaruh dan signifikan terhadap pembiayaan Murabahah.

Dari tabel 9 dapat dilihat bahwa variabel FDR memiliki $t_{\text {hitung }}$ sebesar 1,392 < $\mathrm{t}_{\text {tabel }}$ yang ditetapkan dengan tingkat signifikansi $0,170>0,05$ maka $\mathrm{H}_{2}$ ditolak yang berarti FDR tidak berpengaruh terhadap pembiayaan Murabahah.

d. Analisis MRA (Moderated Regression Analysis)

Moderated Regression Analysis menerapkan pendekatan analiktik yang mempertahankan integrasi sampel dan memberikan dasar untuk mengendalikan pengaruh variabel moderator ${ }^{31}$ persamaan regresi yang diterapkan dalam uji MRA ini adalah sebagai berikut:

$\mathrm{Y}=\mathrm{a}+\mathrm{b} 1 \times 1+\mathrm{b} 2 \times 2+\mathrm{b} 3 \times 1 \times 2 \ldots \ldots$

3) Uji Koefisien Determinasi $\left(R^{2}\right)$

Tabel 11. Hasi Uji $\mathbf{R}^{2}$

Model Summary

\begin{tabular}{|c|c|c|c|c|}
\hline Model & $\mathrm{R}$ & R Square & $\begin{array}{l}\text { Adjusted R } \\
\text { Square }\end{array}$ & $\begin{array}{l}\text { Std. Error of the } \\
\text { Estimate }\end{array}$ \\
\hline 1 &, $561^{\mathrm{a}}$ & 315 & ,243 & 5337,84309 \\
\hline
\end{tabular}

Sumber: Data diolah,2020

Angka Adjusted $R$ Square sebesar 0,243 menunjukan bahwa hanya 24,3\% variabel Pembiayaan Murabahah (Y) yang dipengaruhi oleh variabel CAR (X1) dan FDR (X2) yang dimoderasi oleh variabel NPF, sedangkan sisanya sebesar 85,7\% dipengaruhi variabel lain diluar penelitian ini. Jika dibandingkan dengan nilai $\mathrm{R}^{2}$ sebelum dimoderasi oleh NPF pada tabel 7 sebesar 0,012 atau $1,2 \%$ nilai $\mathrm{R}^{2}$ setelah dimoderasi oleh NPF mengalami peningkatan menjadi 0,243 arau 24,3\% dengan ini dapat disimpulkan bahwa NPF memoderasi pengaruh CAR dan FDR terhadap pembiayaan Murabahah.

e. Uji Simultan (Uji F)

Tabel 12. Hasil Uji F

ANOVA $^{\mathrm{a}}$

\begin{tabular}{|c|c|c|c|c|c|c|}
\hline \multicolumn{2}{|r|}{ Model } & Sum of Squares & Df & Mean Square & $\mathrm{F}$ & Sig. \\
\hline & Regression & 628357254,816 & 5 & 125671450,963 & 4,411 &, $002^{\mathrm{b}}$ \\
\hline 1 & Residual & 1367643305,060 & 48 & 28492568,855 & & \\
\hline & Total & 1996000559,876 & 53 & & & \\
\hline
\end{tabular}

a. Dependent Variable: Murabahah

b. Predictors: (Constant), FDRXNPF, NPF, FDR, CAR, CARXNPF

Sumber:Data diolah, 2020

Dari data diatas dapat dilihat nilai $\mathrm{F}_{\text {hitung }}$ sebesar 4,411. Adapun nilai $\mathrm{F}_{\text {tabel }}$ pada tingkat signifikan $5 \%$ dan derajat dfl $=(\mathrm{k}-1)=2-1=1$ dan df2 $=(\mathrm{n}-\mathrm{k}-1)=55-2-1=52$, maka $F_{\text {tabel }}$ didapat $(1: 52)=4,027$ dengan kata lain $F_{\text {hitung }}>F_{\text {tabel. Nilai signifikansi 0,002 }}$

\footnotetext{
${ }^{31}$ Ibid
} 
lebih kecil dari 0,05, sihingga dapat diambil kesimpulan bahwa penelitan ini menerima $\mathrm{H}_{6}$ yang menyatakan jika NPF memoderasi pengaruh CAR (X1) dan FDR (X2) terhadap Pembiayaan Murabahah (Y) secara simultan

f. Uji Parsial (Uji t)

Tabel 13. Hasil Uji t

\begin{tabular}{|c|c|c|c|c|c|c|}
\hline & \multicolumn{6}{|c|}{ Coefficients $^{\mathrm{a}}$} \\
\hline & \multirow[t]{2}{*}{ Model } & \multicolumn{2}{|c|}{ Unstandardized Coefficients } & \multirow{2}{*}{$\begin{array}{c}\text { Standardized } \\
\text { Coefficients } \\
\text { Beta }\end{array}$} & \multirow[t]{2}{*}{$\mathrm{T}$} & \multirow[t]{2}{*}{ Sig. } \\
\hline & & $\mathrm{B}$ & Std. Error & & & \\
\hline \multirow{6}{*}{1} & (Constant) & 2878,784 & 972,603 & & 2,960 & 005 \\
\hline & CAR & $-150,466$ & 62,915 &,- 800 & $-2,392$ & 021 \\
\hline & FDR & ,038 & ,021 & ,509 & 1,759 & 085 \\
\hline & NPF & 870,595 & 711,213 &, 210 & 1,224 & ,227 \\
\hline & CARXNPF & $-143,763$ & 39,049 & $-2,670$ & $-3,682$ & 001 \\
\hline & FDRXNPF &, 072 &, 018 & 3,001 & 3,945 & 000 \\
\hline
\end{tabular}

Sumber: Data diolah, 2020

Nilai $t_{\text {tabel }}$ yang akan digunakan, dan untuk penelitian ini nilai $t_{\text {tabel }}$ yang ditetapkan adalah (sig. $\alpha=0,025$ dan $\mathrm{df}=53$ ) 2,006 dengan uji dua sisi. Hasil analisis atas hipotesis penelitian $\left(\mathrm{H}_{4}\right.$ dan $\left.\mathrm{H}_{5}\right)$ dapat dilihat sebagai berikut:

4) $\mathrm{H}_{4}$ : Non Performing Financing (M) memoderasi pengaruh Capital Adequacy Ratio $\left(\mathrm{X}_{1}\right)$ terhadap pembiayaan Murabahah.

Dari tabel diatas dapat dilihat bahwa variabel CAR memiliki $t_{\text {hitung }}$ sebesar $-3,682$ maka $t_{\text {hitung }}$ berada di daerah Ho ditolak dan Ha diteriam dengan tingkat signifikansi $0,001<0,05$ maka $_{4}$ diterima yang berarti NPF memoderasi secara signifkan pengaruh CAR terhadap pembiayaan Murabahah.

5) $\mathrm{H}_{5}$ : Non Performing Financing (M) memoderasi pengaruh Financing to Deposit Ratio $\left(\mathrm{X}_{2}\right)$ terhadap pembiayaan Murabahah.

Dari tabel diatas dapat dilihat bahwa variabel FDR memiliki $t_{\text {hitung }}$ sebesar 3,945 lebih besar dari nilai $t_{\text {tabel }}$ yang ditetapkan yakni 2,006 dengan tingkat signifikansi $0,000<$ 0,05 maka $\mathrm{H}_{5}$ diterima yang berarti NPF memoderasi pengaruh FDR terhadap pembiayaan Murabahah.

\section{KESIMPULAN}

Dari pembahasan diatas dapat disimpulkan bahwa CAR tidak berpengaruh signifikan terhadap pembiayaan Murabahah; FDR tidak berpengaruh signifikan terhadap pembiayaan Murabahah sedangkan Tingkat likuiditas suatu bank berpengaruh terhadap pembiayaan Murabahah serta CAR dan FDR secara simultan tidak berpengaruh terhadap pembiayaan Murabahah.

NPF memoderasi secara signifikan pengaruh CAR terhadap pembiayaan Murabahah; NPF memoderasi secara signifikan pengaruh FDR terhadap pembiayaan Murabahah dan NPF memoderasi secara signifikan pengaruh CAR dan FDR terhadap pembiayaan Murabahah secara simultan. 


\section{E. DAFTAR PUSTAKA}

Aziza, Ratu Vien Sylvia, and A D E Sofyan Mulazid. “Analisis Pengaruh Dana Pihak Ketiga, Non Performing Financing, Capital Adequacy Ratio, Modal Sendiri Dan Marjin Keuntungan Terhadap Pembiayaan Murabahah." Jurnal Ekonomi dan Bisnis Islam (JEBI) 2, no. 1 (2017).

Bank Indonesia. "Peraturan Bank Indonesia Nomor 15/12/PBI/2013 Tentang Kewajiban Penyediaan Modal Minimum Bank Umum.” Bank Indonesia (2013).

Efendy, Felix, and Salman Fathoni. "Pengaruh Rasio Kinerja Bank Terhadap Profitabilitas Industri Bank Umum Syariah Di Indonesia.” Jurnal Ilmiah Ekonomi Islam 5, no. 3 (2019).

Ghozali, Imam. "Aplikasi Analisis Multivariate Dengan Program IBM SPSS 21 Update PLS Regresi." Semarang. Badan Penerbit Universitas Diponegoro. ISBN (2013).

Haqqi, Hibatul. "Analisis Pengaruh Non Performing Financing (NPF), Financing To Deposit Ratio (FDR), Inflasi Dan Capital Adequacy Ratio (CAR) Terhadap Proporsi Pembiayaan Murabahah Pada Bank Umum Syariah Di Indonesia.” skripsi (2016).

Indonesia, Bank. Statistik Perbankan Syariah Desember 2019, 2019. https://www.ojk.go.id/id/kanal/syariah/data-dan-statistik/statistik-perbankansyariah/Documents/Pages/Statistik-Perbankan-Syariah---Desember-2019/SPS Desember 2019.pdf.

Joana Ryca Rachmawaty, Farida Idayati. "Analisis Faktor-Faktor Yang Mempengaruhi Pembiayaan Jual-Beli Murabahah Pada Perbankan Syariah Di Indonesia.” jurnal ilmu dan riset manajemen 6, no. 9 (2017).

Kusnianingrum, Devi, and Akhmad Riduwan. "Determinan Pembiayaan Murabahah (Studi Pada Bank Syariah Mandiri).” Jurnal Ilmu dan Riset Akuntansi 5, no. 1 (2016).

Mahardika, Dewa P K. "Mengenal Lembaga Keuangan.” Bekasi: Gramata Publishing (2015).

Marisya, Fitria. "Analisis Pengaruh Struktur Modal (CAR) Dandana Pihak Ketiga (FDR) Terhadap Profitabilitas (ROA) Dengan Kredit Bermasalah (NPF) Sebagai Varibel Intervening Pada Perbankan Umum Syariah Di Indonesia." JAZ:Jurnal Akuntansi Unihaz 2, no. 2 (2019).

Nafidzatun, Nunuk, Mifta Hulaikhah, and Ahmad Arif. "Pengaruh CAR, NPF Dan FDR Terhadap Pembiayaan Murabahah Pada Bank Umum Syariah Di Indonesia." Jurnal Ekonomi Syariah 5, no. 2 (2020).

Oktaviani. “Terhadap Penyaluran Kredit Perbankan ( Studi Pada Bank Umum Go Public Di Indonesia Periode 2008-2011."sk (2012).

Riyadi, Selamet, and Rais Muhcamad Raffii. "Pengaruh Dana Pihak Ketiga, Capital Adequacy Ratio, Bi Rate, Dan Financing To Deposit Ratio Terhadap Pembiayaan Murabahah Pada Bank Syariah Di Indonesia." Perbanas Rerview 3, no. 2 (2018).

Simatupang, H Bachtiar. "Peranan Perbankan Dalam Meningkatkan Perekonomian Indonesia." Jurnal Riset Akuntansi Multiparadigma 6, no. 2 (2019).

Simorangkir, O.P. Pengantar Lembaga Keuangan Bank Dan Non Bank. Bogor: Ghalia Indonesia, 2000.

Sugiyono, P D. "Metode Penelitian Bisnis: Pendekatan Kuantitatif, Kualitatif, Kombinasi, Dan R\&D." Penerbit CV. Alfabeta: Bandung (2017).

Sujarweni, V Wiratna. "Kupas Tuntas Penelitian Akuntansi Dengan SPSS.” Yogyakarta: Pustaka Baru Pers (2016).

Umam, Khaerul. "Manajemen Perbankan Syariah” (2019).

Vivin, Yenni Annor, and Budi Wahono. "Analisis Perbandingan Kinerja Keuangan Bank Umum Syariah Dengan Bank Umum Konvensional Di Indonesia." e-Jurnal Riset Manajemen (2017). 